\title{
Gränsöverskridande blivanden
}

Begär, berättande och etik i Lyra Ekström Lindbäcks Ett så starkt ljus och Hannele Mikaela Taivassalos In transit

Jag vill ha C. Jag vill ha en person som inte verkar stå ut med sin egen person, $i$ alla fall en kropp som inte vill vara närvarande $i$ sin egen kropp. Ett sinnestillstånd som inte vill känna eller erkänna sig självt, som inte orkar, jag begär sådant som hen försöker visa ifrån sig, stänga ute, jag kommer att bli något som hen försöker glömma. ${ }^{1}$

Jag var alltid en tillfällig gäst, alltid på väg bort, någon gång, gärna snart. Samtidigt som mina armar och ben började växa, och brösten, de där små som värkte sig fram, inflammatoriskt, då började också den där lusten gro: att följa de allt längre lemmarna utåt, bort, växa iväg. ${ }^{2}$

BEGÄR KNUTET TILL FÖRÄNDERLIGHET, rörlighet och transgression förenar citaten ovan.Jagberättaren i Lyra Ekström Lindbäcks roman Ett så starkt ljus begär en transperson, någon som inte kan låta sig fästas vid den fysiska gestalt som väcker berättarjagets lust. I klippet ur Hannele Mikaela Taivassalos roman In transit förenas den främsta huvudpersonen Galadriels kropp och längtan i en bokstavlig”wanderlust”, ett begär att följa kroppens förvandlingspotential bort. I båda romanerna gestaltas människor i vardande. Riktningen är oviss. Hos Ekström Lindbäck rör jaget sig mot, och därmed obönhörligen också från, en onåbar och onämnbar annan. Hos Taivassalo är det ett ospecificerat bortom som Galadriels kropp knoppar sig mot. Den gemensamma drivkraften är begäret - ett begär som både blottlägger och utmanar gränser.

Artikeln är skriven med forskningsfinansiering från Svenska kulturfonden.

I. Lyra Ekström Lindbäck, Ett så starkt ljus, Stockholm: Modernista 20I4, s. I29.

2. Hannele Mikaela Taivassalo, In transit, Helsingfors: Förlaget M 20I6, s. 89. 
Föränderligheten är det tredje millenniets enda konstant, hävdar filosofen Rosi Braidotti. Utmaningen för vår tid är följaktligen att tänka i processer snarare än i begrepp. Den centrala frågan är inte längre vilka vi är, utan vilka vi vill bli, hur vi kan gestalta mutationer, förändringar och transformationer framom varat i dess klassiska former. ${ }^{3}$ Genom tematiseringen av transidentitet och ett liv i rörelse ger sig romanerna i kast med två tidstypiska uttryck för föränderlighetens konstans. Ekström Lindbäck och Taivassalo antar båda den utmaning Braidotti formulerar: att gestalta varat som ett blivande.

Idén är inte ny, vare sig litterärt eller teoretiskt. Den öppna, flytande identiteten har präglat hela den nordeuropeiska litteraturen från efterkrigstiden till nuet. ${ }^{4}$ Alltsedan poststrukturalismens postulering av subjektets död har de alternativa sätten att föreställa sig subjektiviteten i termer av föränderlighet och processualitet frodats. ${ }^{5}$ Men vilken angelägenhet har dylika föreställningar i en tid då föränderligheten blivit en konstant? Äger de fortfarande någon maktkritisk sprängkraft? "So what, then?", kan man som Braidotti tillspetsat fråga:

What if the subject is 'trans', or in transit, that is to say no longer one, whole, unified and in control, but rather fluid, in process and hybrid? What are the ethical and political implications of a non-unitary vision of the subject?

3. Rosi Braidotti, Metamorphoses: Towards a Materialist Theory of Becoming, Cambridge \& Malden: Polity Press 2002, s. [I]-2.

4. Se t.ex. Marianne Stidsen, Den ny mimesis. Virkelighedstolkningen i dansk og nordisk litteratur efter Anden Verdenskrig. Bind I: Litteratur, identitet og senmodernitet, København: U press 2015, s. 4-6.

5. Jfr t.ex. Michel Foucault, The Order of Things: An Archaeology of the Human Sciences [Les mots et les choses, I966], översättning av Alan Sheridan, London: Tavistock Publications I980, s. 342. För en idéhistorisk exposé över subjektivitetens I90o-talshistoria, se t.ex. Charles Taylor, Sources of the Self: The Making of the Modern Identity, Cambridge: Cambridge University Press 1992 [1989], s. 456-493.

6. Rosi Braidotti, Transpositions: On Nomadic Ethics, Cambridge \& Malden: Polity Press 2006, s. 9. 'Tänk om subjektet är'trans', eller i transit, det vill säga inte längre ett, helt, enhetligt och kontrollerat, utan snarare flytande, i process, hybridiserat? Vilka är de etiska och politiska implikationerna av en icke-enhetlig syn på subjektet?”. Översättning till svenska: AB. 
Att hävda subjektivitetens föränderliga fluiditet är knappast längre omstörtande, men just därför ter det sig desto viktigare att reflektera över dess vidare implikationer: Hur påverkar detta på en gång anrika och tidsenliga tema samtidslitteraturens uttryck? Vilka spår sätter föreställningar om identitetens rörlighet och begärets kraft och mångfald $i$ hanteringen av berättelsen? Vad kan den litterära gestaltningen av dylika idéer berätta om vad som låter sig sägas och hur?

Mitt val att dryfta dessa frågor just genom Ekström Lindbäcks och Taivassalos romaner bottnar $i$ att deras tematisering av blivande och begär frammanar en både kreativ och kritisk utforskning av berättandet. Därigenom blottlägger de angelägna formmässiga och etiska aspekter av berättelsens möjligheter och begränsningar som kan bidra till förståelsen av litteraturens nu. Teoretiskt närmar jag mig romanerna genom en kombination av genusvetenskapliga och litteraturvetenskapliga perspektiv. Vid sidan om Braidottis feministiskt nymaterialistiska teoretisering av blivande hör Hanna Meretojas reflektioner kring berättelsen som form för etisk undersökning till de viktigaste analysverktygen. ${ }^{7}$ Genom att föra samman dessa perspektiv kommer jag åt skärningspunkterna mellan litteratur och maktkritik, form och tematik, berättande och subjektivitet, narrativ och etik.

Begär som motor för transformationer och transgressioner förenar Ekström Lindbäcks skildring av kärlek i en stockholmsk hbtqi-tillvaro och Taivassalos lustfyllda utforskning av liv i genomfart. Men romanerna uppvisar också skillnader genom sina olika strategier att berätta blivande och begär - strategier som, vill jag hävda, blottlägger etiska dimensioner hos berättandet och demonstrerar olika sätt att hantera dessa. Genom en komparativ analys strävar jag efter att synliggöra de kopplingar romanerna tecknar mellan det begärsdrivna blivandet och berättelsens etik. Artikelns syfte är att utröna hur gestaltningen av blivande och begär avtecknar sig $i$ hanteringen och tematiseringen av berättandet, vilka etiska aspekter av berättandet som därmed framträder och vad Ekström Lindbäck och Taivassalo gör av dem. De

7. Hanna Meretoja, The Ethics of Storytelling: Narrative Hermeneutics, History, and the Possible, Oxford: Oxford University Press 2018, https://doi.org/ro.1093/ oso/9780190649364.0or.ooor. 
konkreta frågor och verktyg med vars hjälp jag tar mig an detta syfte går jag närmare in på i följande avsnitt.

Det är två olikartade författarskap ur olika delar av den svenska litteraturen jag för samman i min läsning. Taivassalo (f. 1974) debuterade 2005 med noveller och har sedan dess etablerat sig som en av Svenskfinlands tongivande författare med såväl romaner som dramatik och barnböcker kring teman som uppbrott och återkomst samt flickors och kvinnors egenmakt. Stilistiskt rör hon sig i gränslandet mellan poesi och prosa. Den rikssvenska Ekström Lindbäcks (f. I990, numera gift Koli) författarskap inleddes senare och är mindre omfattande. Hon debuterade 2012 med metaromanen Tillhör Lyra Ekström Lindbäck. ${ }^{8}$ Sedan dess har hon gett ut ytterligare tre romaner och debuterar som poet hösten 20I9. I hennes motivkrets ingår liv bortom heteronormativiteten, ung vuxenhet, skrivande och människans relation till naturen. Formmässigt har hon gått från det utpräglat metalitterära mot ett rakare berättande. Målsättningen med den komparativa analysen är inte att spåra eventuella givna samband eller inbördes influenser mellan författarskapen. Genom att ställa primärtexterna i relation till varandra strävar jag efter en korsbelysning där sätten att förstå och hantera berättande, begär och etik i respektive roman framträder.

Författarna har trots framgångar ännu inte väckt större vetenskaplig uppmärksamhet. ${ }^{9}$ Ekströms Lindbäcks författarskap har ännu inte varit föremål för djupare studier.Jag har själv tidigare gjort en essäistisk analys av Taivassalos In transit med fokus på rörlighet. ${ }^{10} \mathrm{I}$ övrigt är det främst Taivassalos vampyrroman Svulten ${ }^{11}$ som har undersökts, grundligast av Pirjo Lyytikäinen som läst den i ljuset av dekadensens litterära tradition. ${ }^{12}$ Kristina Malmio lyfter fram Svulten och Taivassalos

8. Lyra Ekström Lindbäck, Tillhör Lyra Ekström Lindbäck, Stockholm: Modernista $2 \mathrm{OI} 2$.

9. Taivassalos romandebut belönades med Runebergspriset 2008 och 2017 erhöll hon den Längmanska kulturfondens Finlandspris för sitt författarskap. Ekström Lindbäck vann Lilla Augustpriset redan 2008 och Ett så starkt ljus nominerades till Augustpriset 2014 .

Io. Freja Rudels,"Fängslande förflyttningar. Rörelsen som livsmanus i Hannele Mikaela Taivassalos In transit", Anna Möller-Sibelius \& Freja Rudels (red.), Modernitetens uttryck och avtryck. Litteraturvetenskapliga studier tillägnade professor Claes Ablund, Åbo: Föreningen Granskaren 20I7, s. I49-158.

II. Hannele Mikaela Taivassalo, Svulten, Helsingfors: Schildts \& Söderströms 2013.

I2. Pirjo Lyytikäinen,"Dekadenssin hirviönaisten paluu? Naisvampyyri ja hänen kirjal- 
romandebut Fem knivar hade Andrej Krapl ${ }^{13}$ i en artikel om centrala tematiska och berättartekniska drag i finlandssvenska 2000-talsromaner, där hon skönjer en övergång från postmodernistisk skepsis till ett mer bejakande förhållningssätt till berättelsen. ${ }^{14}$ Den utprövning av berättelsen som utspelar sig i Taivassalos och Ekström Lindbäcks romaner tangerar den här diskussionen. Min läsning tjänar således inte bara till att belysa de romaner jag analyserar utan kan också bidra till kunskapen om berättelsens roll i den svenskspråkiga litteraturens nu.

Härnäst introducerar jag de teoretiska diskussioner kring berättande, begär och etik genom vilka jag studerar romanerna. Därpå följer en komparativ närläsning av primärmaterialet där jag först undersöker romanernas tematiska och formmässiga fokus på mellanrum och hur mellanrummen förkroppsligas i visioner av subjektiviteten. Därefter diskuterar jag de vägar ut ur normerande mönster för både liv och narrativ som visionerna stakar ut, för att sedan visa hur denna utbrytning löper genom litterära mönster och traditioner mot en bejakelse av berättelsen. Slutligen ringar jag in parallelliteten mellan berättande och begär i romanerna. Jag dryftar de relationella dimensioner av berättelsen som denna parallellitet uppdagar och visar hur dessa blottlägger de etiska implikationerna av romanernas sinsemellan olika berättartekniska strategier.

\section{BERÄtTANDE, ETIK OCH BEg ÄR}

Berättelsens etik begränsar sig inte till vad berättelsen handlar om. Etiken innefattar också formen: det sätt på vilket berättelsen handlar. Adam Zachary Newton talar om berättelsen som etik i sig själv, och syftar därmed på den narrativa strukturen som en etisk relation. I linje med Gérard Genette definierar han berättande som den fiktiva eller

linen perimänsä Hannele Mikaela Taivassalon romaanissa Nälkä’, Viola ParenteČapková et al. (toim.), Nainen kulttuurissa, kulttuuri naisessa, Turku: Turun yliopisto 2015, s. 18I-204.

13. Hannele Mikaela Taivassalo, Fem knivar hade Andrej Krapl, Helsingfors: Söderströms 2007.

I4. Kristina Malmio, "Vanhat ja uudet leikit. Suomenruotsalaisen romaanin keskeiset teemat ja kerrontatavat 200o-luvulla", Elina Arminen \& Markku Lehtimäki (toim.), Muistikirja ja matkalaukku: 20oo-luvun suomalaisen romaanin muotoja ja merkityksiä, Helsinki: Suomalaisen Kirjallisuuden Seura u.u. 
faktiska handling som producerar både berättelsen och storyn. Det är en handling som enligt Newton medför ansvar vid sidan om form. ${ }^{15}$ Newtons syn på etik genomsyras av Levinas dito, där relationen till den Andre står i centrum. Prosan översätter, enligt Newton, etikens interaktiva problematik till litterära former genom de intersubjektiva relationer den tecknar, relationer som skapar och förbinder berättare och lyssnare, författare och karaktär, läsare och text med varandra. ${ }^{16}$

Berättelsens förmåga att förena, och därmed också att skilja åt, är en aspekt av berättelsens etiska potential som även Hanna Meretoja lyfter fram. Hennes perspektiv är hermeneutiskt och hon framhäver följaktligen tolkningens betydelse. Med tolkning avser hon inte ett predestinerat sökande efter en given mening utan en ständig produktiv process som utgör en ofrånkomlig del av vår existens. Med utgångspunkt i Nietzsches idé om att det inte finns några fakta, bara tolkningar, betraktar Meretoja berättelsen som en form av tolkning och därmed omtolkning av de nätverk av kulturella narrativ som kringgärdar och formar vår existens. ${ }^{17}$ Som sådan äger berättelsen kraft att omforma vår syn på verkligheten och således vår uppfattning om det möjliga:

\begin{abstract}
Each cultural and historical world functions as a space of possibilities that encourages certain modes of experience, thought and action, and discourages or disallows others, and stories play a constitutive role in establishing the limits of these worlds - both enabling experience and delimiting it. ${ }^{18}$
\end{abstract}

Förmågan att påverka vår känsla för vad som är möjligt är, enligt Meretoja, berättelsens främsta etiska potential. ${ }^{19}$ Ett av sätten på vilka berättelsen kan förskjuta gränserna för det möjliga lokalise-

15. Adam Zachary Newton, Narrative Ethics, Cambridge \& London: Harvard University Press 1997 [1995], s. 3-8, https://doi.org/ro.2307/j.ctvjf9vcx.

I6. Ibid., s. I2-I3.

I7. Meretoja, The Ethics of Storytelling, s. 6, 43-54.

I8. Ibid., s. 2, kursiv i originalet. "Varje kulturell och historisk värld fungerar som en rymd av möjligheter som uppmuntrar vissa former av erfarenhet, tanke och handling, och motarbetar eller vägrar att erkänna andra. Berättelser spelar en avgörande roll i gränsdragningen kring dessa världar genom att både möjliggöra och begränsa erfarenheter." Ovversättning till svenska: FR.

I9. Ibid., s. 89-97. 
rar Meretoja till de "narrativa mellanrummen"20; de intersubjektiva kontaktytor av inkludering - och därmed också exkludering - som berättelser frammanar exempelvis genom att skriva fram och ringa in ett "vi" och därmed även skapa ett "de". De narrativa mellanrummen kan röra alla intersubjektiva sfärer, från de allra intimaste till de globala. De kan både fungera begränsande, genom att befästa rigida identiteter och låsta konstellationer i "vi" och "de", och expanderande, som inklusiva utrymmen där skillnader bejakas och transformativa

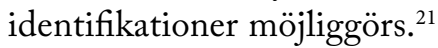

Alltifrån dess innersta strukturer till den yttersta räckvidden av dess effekter inbegriper berättelsen mellanmänskliga bindningar och därmed också etisk angelägenhet. Det innebär dock inte att berättelsen per automatik skulle vara etisk i betydelsen moraliskt god. Newtons etik syftar på en relation som föregår och sträcker sig utöver frågor om gott eller ont och rätt eller fel. Hos Meretoja är det etiska mer av en värderingsfråga - berättelser som vidgar vår uppfattning om vad som är möjligt ter sig mer etiska i hennes resonemang än berättelser som inskränker denna. Hon betraktar ändå inte det etiskt goda och riktiga som en given egenskap hos berättelsen, utan som en potential den har. Newton och Meretoja slår båda en kil mellan föreskrivna moraliska normsystem och etiken vars uppgift är reflektion. ${ }^{22}$ "[I]nstead of conveying moral truths or rehearsing our ability to detect them, literature can function as a form of ethical inquiry in its own right”, skriver Meretoja, och påpekar att berättelsens etiska relevans ligger i frågorna den uppdagar, inte i svaren den ger. ${ }^{23}$ Både Ekström Lindbäck och Taivassalo tar oss bortom det givna och föreskrivna och frågan som infinner sig är hur de hanterar den etiskt laddade

20. Ibid., s. II7-I25. "Narrative in-betweens".

2I. Ibid.

22. Newton, Narrative Ethics, s. 4-5, 9, I3; Meretoja, The Ethics of Storytelling, s. I4, not 25 s. 40. Här skiljer de sig från andra auktoriteter inom narrativ etik. T.ex. Phelan betraktar etik som synonymt med moral i sin exposé över fältet. Se James Phelan, "Narrative Ethics", Peter Hühn et al. (eds.), The Living Handbook of Narratology, Hamburg: Hamburg University 20I4, http://www.lhn.uni-hamburg.de/article/ narrative-ethics (hämtad 26/ı 2018).

23. Meretoja, The Ethics of Storytelling, s. I34-I35. "[I] stället för att uttrycka moraliska sanningar eller öva upp vår kapacitet att upptäcka sådana, kan litteraturen fungera som en form av etisk undersökning i sin egen rätt.” Översättning till svenska: FR. 
relation som berättandet innebär då både självet och den andra är stadda i förvandling. Vilka former antar de narrativa mellanrummen då? Och vad kännetecknar en etisk relation när dess kontrahenter befinner sig in transit?

I förhållande till dessa frågor blir romanernas skildring av begär intressant, som en explicit tematisering av det relationella. Eftersom jag vill synliggöra hur begär förstås och gestaltas i romanerna utgår min läsning inte från någon entydig och given definition av begär. I stället stöder jag mig på element ur Braidottis tankar kring begär vars mångfasetterade öppenhet erbjuder rymd för primärmaterialets komplexitet. Begäret intar en central position i Braidottis feministiska nymaterialism. I linje med Spinoza och Deleuze framhäver hon det positiva i begäret som en framåtdrivande kraft, en ständigt skiftande horisont som genererar möten, sammansmältningar och gränsöverskridanden. ${ }^{24}$ Braidotti kombinerar denna produktiva begärsförståelse med en könsskillnadsfeministisk betoning av subjektivitetens kroppsliga materialitet, inte som en biologisk essens men som en komplex samverkan mellan sociala och symboliska krafter. Hon poängterar begärets centrala roll i subjektskonstitutionen och understryker dess politiska relevans i egenskap av libidinös och framför allt ontologisk drivkraft: som ett grundläggande begär att vara. ${ }^{25}$ Braidottis teoretisering av begäret tecknar kopplingar mellan begär och gränsöverskridande, mellan kropp och subjektivitet, sexualitet och ontologi, lust och politik. Dessa kopplingar tjänar som verktyg för min analys av hur blivande och begär vävs samman i Taivassalos och Ekström Lindbäcks romaner och hur såväl erkännandet av som potentialen $\mathrm{i}$ subjektiviteten knyts till det kroppsliga.

I och med att det rör sig om romaner och därmed om berättad kroppslighet röjer begäret inte bara kroppens utan också berättelsens

24. Se t.ex. Braidotti, Metamorphoses, s. Ioo.

25. Ibid., s. 20-23. Braidottis könsskillnadsfeminism, inspirerad av Luce Irigaray, upprätthåller inte idén om en essentiell kvinnlighet. Det rör sig om en strävan att formulera alternativa, förkroppsligade och därmed könade subjektspositioner i syfte att punktera exkluderande uppfattningar om subjektiviteten som förment neutral och göra upp med en dualistisk tanketradition där femininitet kopplas till underlägsenhet och där skillnad tolkas i pejorativa termer. Jfr Freja Rudels, I berättandets makt. Om tre romankroppar av Per Olov Enquist, Åbo: Åbo Akademis förlag 20I6, s. 4I-43. 
möjligheter och begränsningar. Vad låter sig berättas? Vilka kroppar och kroppsliga erfarenheter får plats inom de narrativa mönster vi har att tillgå? Vilka faller utanför? Och vilka kan skrivas fram? Inom den hermeneutiska tradition Meretoja företräder rivs den klassiska motsättningen mellan liv och dikt upp. Berättelser betraktas inte som retrospektiva förvrängningar av levd erfarenhet, utan fokus riktas $\mathrm{i}$ stället mot de komplexa sätt på vilka våra liv är inlemmade i och formade av kulturellt traderade berättelser. I linje med detta synsätt föreslår Meretoja en bred förståelse av metanarrativitet. Som metanarrativa definierar hon berättelser som gör berättandet till tematik och behandlar berättelsens betydelse för den mänskliga existensen generellt. ${ }^{26}$ Det är dylika, vidsträckta dimensioner av berättelsen och berättandet som mitt primärmaterial ger anledning att dryfta. För att komma åt ett specifikt kulturellt narrativ som spelar en central roll i båda romanerna åberopar jag därtill queerteoretikern Judith (numera Jack) Halberstams tankar kring hur vi förväntas leva enligt ett av reproduktionen dikterat och konventionen upprätthållet tidsschema - ett slags livsmanus. ${ }^{27}$ Dessa tankegångar bidrar både till att synliggöra hur berättelsen undersöks, problematiseras och bejakas i primärmaterialet och till att blottlägga berättelsens normerande och omstörtande dimensioner.

\section{FörKROPPSLIGADE MELLANRUM}

I båda romanerna intar olika former av mellanrum en central position. Härnäst dryftar jag hur mellanrummen kommer till uttryck, hur mellanrummen förkroppsligas i de alternativa visioner av subjektiviteten som frammanas i romanerna och hur de därmed utrustas med etisk angelägenhet.

Redan definitionen av "in transit" i ingressen till första delen av Taivassalos roman tar läsaren till ett mellanrum: "In transit, transito, min vän / eller / mitt hjärta är så osäkert och vagt / eller / In transit:

26. Hanna Meretoja, The Narrative Turn in Fiction and Theory. The Crisis and Return of Storytelling from Robbe-Grillet to Tournier, Basingstoke: Palgrave Macmillan 2014, s. 3, I7-18, https://doi.org/10.1057/9781137401069.

27. Judith Halberstam, In a Queer Time and Place: Transgender Bodies, Subcultural Lives, New York \& London: New York University Press 2005, s. I-5. 
Mellan där du är och där du aldrig visste att du skulle vara." ${ }^{28}$ Begreppet, titeln och därmed hela romanen, lokaliseras till en övergång mellan ett givet här och ett oanat bortom. Samtidigt demonstreras mellanrummet genom de ingångar ingressen tecknar. Läsaren ställs inför, och därmed mellan, alternativa vägar genom texten. Du-tilltalet griper efter en mottagare. Jagformen ger en subjektiv, emotionell och existentiell förankring och begreppsdefinitionen signalerar en teoretiskt reflexiv dimension. Sammantagna illustrerar de parallella ingångarna den stilistiska vidden i romanbygget, från det lyriska till det realistiska och det filosofiska.

Också tematiskt är det i övergångarna In transit placerar sig. Romanen löper mellan tre personer från samma släkt och samma anonyma landsbygd i vad som förefaller vara Österbotten. Det är jordbrukarsonen Sem som en gång åkte iväg på hamnarbete till Stockholm där han också fick leva ut sin förträngda homosexualitet. I romanens nu har han övertagit gården, gift sig, avlat tre barn och lever som en åldrande änkling hemsökt av minnena från Stockholmsparentesen. Ibland får han besök av svägerskan Vera. Hon har också brutit upp från bygden, åkt till Helsingfors för att "arbeta och dansa" och, likt Sem, funnit en förbjuden kärlek hon har tvingats överge och sedan återvänt till byn, till den ena halvan av ett gult parhus. I den andra halvan flyttar Galadriel in. Hon är Sems barnbarn och även hon på flykt undan en förbjuden kärlek, hemkommen från ett liv som tagit henne genom tre kontinenter.

Huvudpersonerna är tre, men perspektiven fler. Det är inte sällan olika bifigurer ger sin blick på skeendena. I en återkommande "Resedagbok" möter vi ett skrivande jag, ett alter ego till författaren som befinner sig på transitplatser som flygfält och hotell och reflekterar över rörelse. Romanen består av löst sammanhållna avsnitt och kan sägas vara på väg också den. Avsnitten är ofta försedda både med en rubrik och en modifierande parentes, som om de var ryckta direkt ur anteckningsboken. Den opolerade öppenheten i kombination med de djärva klippen mellan tider och perspektiv bidrar till intrycket av att det är mellan snarare än $i$ de enskilda livsödena romanens handling utspelar sig.

28. Taivassalo, In transit, s. [7], kursiv i original. 
Räckvidden är betydligt mindre i Ett så starkt ljus, men även här får mellanrummen en framträdande roll. Huvudpersonen och jagberättaren Sara driver dag i Stockholm. Hon befinner sig på tröskeln till vuxenhet, bor i en tillfällig studentbostad, sysselsätter sig med diverse studier och framför allt med att analysera och formulera sin tillvaro. Romanen påminner om en dagbok, och det är dess koncipiering $\mathrm{i}$ förädlad form som bildar romanens övergripande intrig. Vägen till boken löper genom en räcka kärlekar som har ett gemensamt: de förblir i mellanrummet mellan förälskelse och förlösning. I Saras förälskelser spelas en kavalkad av sexuella identiteter upp. Den aspirerande skådespelerskan Joanna briljerar i sitt bemästrande av femininitetens repertoar och intresserar sig för Sara som en möjlighet att få spela rollen som lesbisk. Sara identifierar sig som lesbisk och för henne är flirten med Joanna allvar. Som motvikt till Joannas dramatiska gestalt infinner sig den slätstrukna ungdomsförälskelsen Linnéa i Saras liv och meddelar att hon tror sig vara asexuell.

Relationerna till Joanna och Linnéa fungerar som byggstenar i romanens emotionella och intellektuella upptrappning mot den kulmen C:s inträde utgör:

"Vi har träffats förut, eller hur?" säger Joanna och flyttar sin stol åt sidan för att visa att hen är välkommen att slå sig ned runt bordet. "Men jag minns inte ditt namn."

"Se", svarar hen och tar en stol från väggen, makar försiktigt in den mellan mig och Joanna.

"Se? Som i titta?", frågar hon roat, och jag behärskar min lust att sparka henne i smalbenet.

"Som i bokstaven C", svarar hen lugnt och vänder sig mot mig i stället. ${ }^{29}$

När C på en premiärfest bokstavligen kilar in sig mellan Joanna och Sara ger hen mellanvarat en skepnad."Se" misstolkar Joanna namnet och sätter ord på den uppmaning hela C:s gestalt kan sägas utgöra. Hens närvaro fungerar som det starka ljus som tvingar fram både

29. Ekström Lindbäck, Ett så starkt ljus, s. I2I. 
Saras författarblivande och det normkritiska, självrannsakande seende som bildar romanens nerv.

Med Braidotti kunde $\mathrm{C}$ beskrivas som en figuration, som en kritiskt kreativ vision av subjektiviteten. Figurationer fungerar som förkroppsligade kartläggningar av de maktordningar som kringgärdar subjektet, samtidigt som de uppenbarar alternativa sätt att förstå subjektiviteten som flerskiktad, dynamisk och föränderlig till skillnad från alltjämt förhärskande föreställningar om subjektiviteten som given, fast och enhetlig. Braidottis figuration par excellence är nomaden, en inkarnation av situerad rörlighet som riktar fokus mot övergångar och förskjutningar i och kring subjektet. ${ }^{30}$ Det är just sprängkraften i det rörliga som framträder i C:s undflyende skepnad. Samtidigt är hens konkreta rörlighet väldigt liten. Den är begränsad till den alternativa kulturvärld hen och Sara befolkar och mestadels till hens lilla lägenhet. Kringskurenheten framhävs ytterligare när hen blir intagen till följd av psykiska problem. Det rörliga i C sitter i C, i hens förkroppsligande av mellanrummet mellan manligt och kvinnligt, och i kroppens skavande oförmåga, i det glapp mellan fysisk gestalt och inre upplevelse som frammanas i "en kropp som inte vill vara närvarande i sin egen kropp". ${ }^{31}$

Även Galadriel i Taivassalos roman låter sig läsas som en figuration och hennes kringflackande liv påminner uttryckligen om nomadens. Från första början är hennes karaktär demonstrativt svårgripbar. Hon beskrivs som ett alldagligt barn, ett barn som vem som helst hade kunnat ta hem från dagis. Hennes namn vetter dock i motsatt riktning. Hämtat ur Tolkiens värld ger det henne ett fäste i en sfär bortom vardagen och realiteterna. Av sin lillebror "Gullebjörnen" har hon dessutom fått smeknamnet "Häst". ${ }^{32}$ I Galadriels gestalt avtecknar sig en motsägelsefull spännvidd - en övergång. Hon är alldaglig intill utbytbarhet och samtidigt upphöjt litterär, en tabula rasa försedd med en redan författad förlaga. I smeknamnet från djurriket bor en antydan

30. Rosi Braidotti, Nomadic Subjects: Embodiment and Sexual Difference in Contemporary Feminist Theory, New York: Columbia University Press 1994, s. I-8; Braidotti, Metamorphoses, s. 2-Io, I3. För en utförligare diskussion av begreppet "figuration" hos Braidotti, se Rudels, I berättandets makt, s. 39-40.

3I. Ekström Lindbäck, Ett så starkt ljus, s. I29.

32. Taivassalo, In transit, s. I3-I5. 
om den lek med gränsen mellan natur och kultur som genomgående kan skönjas i hennes framhävt fysiska begär.

Det ofixerbara utgångsläget genljuder i Galadriels mammas beskrivning av den unga dottern som "vag". ${ }^{33}$ Själv värjer Galadriel sig mot formuleringen, men medger att hon aldrig varit särskilt förankrad i sin uppväxtmiljö, utan alltid uppfylld av en törst efter något avlägset. I hennes ungflicksdrömmar projiceras törsten på Fridtjof Nansen och tar sig uttryck i en våldsam fantasiförälskelse med "kroppar som dunkade in mot relingen och mot varandra och lust och nyfikenhet att upptäcka, äventyrligt mot vilka poler som helst, vilka extremer som än kom oss till mötes". ${ }^{34}$ Det vaga i Galadriel handlar om avsaknad av ett definierande fäste i ursprunget. Det är ur detta, som mamman påtalar som en brist, som Galadriel formulerar sin kapacitet: styrkan i hennes förmåga att känna. Vagheten framträder som en förutsättning för kapaciteten att begära något annat, att om och om igen överskrida utgångspunkten och därmed överge idén om en tydlig, given identitet till förmån för transitvarats öppenhet.

I C och i Galadriel tar romanernas utforskning av mellanrummen kropp. Därmed kopplas mellanrummen till frågor om subjektivitet och identitet, till den etiskt laddade frågan om vad en människa är, samt till grundmurade förväntningar på hur vi ska vara och leva och till möjligheterna att omformulera dessa förväntningar.

\section{BEG̈̈R BORTOM MANUS}

Det är i dialog med nätverk av preexisterande kulturella narrativ som vår identitet formuleras, hävdar Meretoja. Dessa narrativ är utrustade med en inneboende normativitet; repertoaren av tillgängliga narrativ sätter gränser för vem och vad vi kan vara. ${ }^{35}$ Rörelsen bortom det förväntade och föreskrivna är i båda romanerna förknippad med blottläggning av och utbrytning ur vad som kan betraktas som normerande kulturella narrativ.

33. Ibid., s. 89 .

34. Ibid., s. 90 .

35. Meretoja, The Ethics of Storytelling, s. 74-85, särskilt s. 83 . 
I Ekström Lindbäcks roman fungerar $\mathrm{C}$ som den främsta vägvisaren. Året innan pronomenet "hen" upptogs i den fjortonde upplagan av SAOL demonstrerar Ett så starkt ljus ordets möjligheter. $\mathrm{C}$ omtalas konsekvent som hen. Därmed röjer Ekström Lindbäck en plats bortom en binär könsordning. Samtidigt synliggör hon vidden av den normerande och exkluderande kraften i denna könsordning, en kraft som ter sig intimt sammanbunden med ett narrativt mönster:
"[...] Är han transsexuell förresten? Eller hon? Första gången jag träffade $\mathrm{C}$ så tänkte jag att det var en kvinna som ville vara en man, och andra gången att det var en man som ville vara en kvinna." "Eller ingendera som vill vara ingendera", svarar jag tonlöst. ${ }^{36}$

C:s ickebinära könsidentitet reduceras i Joannas undring till en tillfällig övergång, en parentes mellan en utgångspunkt och ett mål där det enbart finns rum för man eller kvinna. Joannas frågor blottar en cisnormativ föreställning om att kön och identitet bygger på de fasta könskategorierna man och kvinna och att alla primärt identifierar sig enligt det biologiska kön de tillskrevs vid födseln. I likhet med den mer vedertagna heteronormativiteten som utgår ifrån heterosexualitetens primat, utgör cisnormativiteten ett diskursivt system som kan sägas staka ut gränserna för det kulturellt igenkännbara. ${ }^{37}$ Joannas önskan att hänföra $\mathrm{C}$ till en för henne begriplig könsidentitet demonstrerar den begränsande kraften i detta system och belyser också den narrativa logik som systemet vilar på. Joanna frågar efter ett definierande ursprung eller ett slutgiltigt mål. Hon vill höra C:s identitet formuleras som en lineär progression med en början och ett slut. Denna förväntning omintetgörs i Saras svar. Ingendera som vill bli ingendera trotsar inte bara en binär könsordning utan också den konventionella berättelsens mest grundläggande beståndsdelar. Saras svar sammanfattar en central aspekt både av romanens handling och av hur den hand-

36. Ekström Lindbäck, Ett så starkt ljus, s. I77-I78.

37. Se t.ex. Iwo Nord, Signe Bremer \& Erika Alm, "Redaktionsord: Cisnormativitet och feminism", Tidskrift for genusvetenskap, 37, 2016:4, s. 3-13. Jfr Judith Butler, Gender Trouble. Feminism and the Subversion of Identity, New York \& London: Routledge I999 [I990], s. 42-43, https://doi.org/Io.4324/9780203902752. 
lar, det sätt på vilket den hanterar den handling berättelsen utgör. ${ }^{38}$ Ekström Lindbäck söker sig bortom lineariteten och progressionen, och denna rörelse innefattar såväl subjektiviteten och identiteten som själva berättandet.

Här spelar uppgörelsen med ett specifikt kulturellt narrativ en avgörande roll. Halberstam framhåller reproduktionens betydelse för hur vi organiserar våra liv. Enligt Halberstam bygger en dominerande föreställning om ett normalt och respektabelt liv på en heteronormativ medelklassidé om livet som en mognadsprocess där reproduktionen utgör mål och mening och styr hela vår tidsuppfattning. Denna föreställning dikterar vad vi förväntas uträtta och uppnå och i vilken ordning. Den tjänar som ett slags livsmanus utgående ifrån vilket vi lever och värderar våra liv. I relation till detta livsmanus avtecknar sig livslinjer som inte är inställda på framåtskridande, mognad och återväxt - på reproduktionstid - som skeva. ${ }^{39}$

Ett dylikt livsmanus genljuder i Ett så starkt ljus. Sara befinner sig på tröskeln till vuxenhet, i det Halberstam beskriver som "the dangerous and unruly period of adolescence". ${ }^{40}$ Det finns dock inga tecken på att hon är på väg att mogna ur denna period på det konventionellt önskvärda sättet, med ett stabilt familjeliv som hägrande mål. När hon återser vänner från skoltiden uppfattar hon deras kallprat som

trivialiteter de plöjer igenom på väg mot sina riktiga liv, en klättring mot karriärer och bostadsrätter och familjer, en förväntad och lycklig livsutveckling som det här muntra babblet bara är en harmlös passage till. ${ }^{41}$

Mönstret hon ser och genomskådar är det förväntade, men det är inte hennes att följa. För henne är det obeständiga nuet ingen harmlös passage, utan en mittpunkt. När hon ser föräldrar baxa in barnvagnar i spårvagnen konstaterar hon att det är ett problem som inte angår

38. Jfr Newton, Narrative Ethics, s. 7 .

39. Halberstam, In a Queer Time and Place, s. I-7.

40. Ibid., s. 4, "Den farliga och oregerliga ungdomstiden”. Översättning till svenska: FR.

4I. Ekström Lindbäck, Ett så starkt ljus, s. 65. 
henne och "antagligen aldrig kommer att göra det heller". ${ }^{42}$ Under ett av sina nattliga samtal med C:s och hennes gemensamma vän Emil läser hon de mörka fönstren i husfasaden mittemot som ett vittnesmål om hur "alla vanliga människor ska upp till sina arbeten i morgon". ${ }^{43}$ Vanliga människors vanliga liv är inte Saras, eller C:s eller Emils att leva. Halberstamskt skeva vägrar deras livslinjer progressionen - genom såväl livet som dygnets timmar.

De alternativa livslinjer Ekström Lindbäck tecknar blottlägger de förväntningar som vidhäftar ett livsmanus inställt på reproduktion och tecknar en alternativ väg - ett improduktivt, reflekterande stillastående. Samtidigt infinner sig frågan om de normer Ekström Lindbäck skriver fram, och låter sina personer bryta mot, verkligen är så normerande. Att åtta till fyra-verkligheten faktiskt skulle vara den som definierar "alla vanliga människor" ter sig aningen generaliserande och förlegat. Inte minst då scenen är Stockholm dit folk i generationer sökt sig just för att få leva på alternativa sätt; att det är i Stockholm Taivassalo låter sin Sem leva ut sin homosexualitet vittnar exempelvis om en stad bortom "det vanligas" tyranni. I sin tolkning av tillvaron ter sig Sara synnerligen upptagen med att själv kringskära sin existens. Noteras kan att det är hon själv, inte samhället och inte någon annan, som avskriver reproduktionen som livsutsikt. Hennes benägenhet att aktivt utesluta möjligheten understryker romanens strävan att röja rum för andra sätt att vara och på så sätt blottlägga och trotsa kopplingen mellan normalitet och reproduktion, mellan fullvärdig vuxenhet och familjeliv med barn.

Att de förväntningar på olika former av progression som Ekström Lindbäck brottas med fortfarande äger en normerande kraft vittnar receptionen av romanen om. I denna återkommer en tendens att begränsa romanens giltighet till ett visst livsskede."Det är en roman om en tid i livet som även vi som lämnat den bakom oss ibland behöver återvända till även om det gör ont. För att förstå oss själva och varför vi blev som vi blev", skriver Annina Rabe. ${ }^{44}$ Hon framhåller därmed underförstått en uppfattning om att den tid Ekström Lindbäck skildrar

42. Ibid., s. I36.

43. Ibid., s. I96.

44. Annina Rabe, "Kärleken i hjärnan", Expressen 22/10 2014. 
ska övergå i ett mål där vi funnit vår form och kan blicka tillbaka på en fas som var formerande och viktig, men framför allt övergående. Pia Bergström råder i sin recension den "begåvade unga författaren [...] att levandegöra hellre än att försöka begripa och bemästra den värld hon vill skildra”. Samtidigt konstaterar hon att det kräver en distans man inte har när man är $23 .{ }^{45}(\mathrm{Be})$ mästrandet tycks vara förbehållet de fullvärdigt vuxna. Det analytiska anslaget hos Ekström Lindbäck, det hon uppvisar av intellektuell mognad, blir för Bergström ett utslag av hennes ringa ålder. Det distanserade i framställningen blir paradoxalt nog ett uttryck för bristande distans. Lars Hermansson är inne på samma linje när han beskriver romanen som "en fallstudie över en människa instängd i sitt eget språk och i sina grandiosa föreställningar om sig själv” och konstaterar att det är en vanlig åkomma både hos romangestalter och människor i $20-30$-årsåldern. ${ }^{46}$ Författaren och hennes hjältinna famnar efter för mycket och för lite, och båda bristerna härleds till den unga vuxenhetens avsaknad av självinsikt och beredskap att ta in omvärlden.

Kritiken mot den odistanserade distansen går hand i hand med ett missnöje med romanens brist på handling."Berättelsen kommer inte loss", anser Bergström. ${ }^{47}$ "Det talas och tolkas och tolkas och talas, men mycket lite händer", skriver Hermansson. ${ }^{48}$ Denna otillfredsställdhet kopplas vidare till begärsskildringen. Romanen beskrivs som "kysk", ${ }^{4}$ "cerebral" och "nästan helt renons på sexualitet". ${ }^{50}$ Kritiken sätter ord på den parallellitet mellan tematik och berättarteknik som genomsyrar romanbygget, på hur romanen i linje med de liv den skildrar konsekvent avstår från att förverkliga våra djupt rotade förväntningar på att en sak obönhörligen måste leda till någonting annat. Det recensenterna inte uppmärksammar är i hur hög grad denna vägran och tvekan handlar om mer än ord, språk och tolkning - hur den konstant

45. Pia Bergström, "Lesbisk jakt efter identitet och flickor", Aftonbladet 27/ro 2014.

46. Lars Hermansson,"'Ett så starkt ljus'av Lyra Ekström Lindbäck", Sveriges Radio, Kulturnytt i PI 20/IO 20I4, http://sverigesradio.se/sida/artikel.aspx?programid =478\&artikel=5996035 (hämtad 30/ı 2017).

47. Bergström, "Lesbisk jakt efter identitet och flickor".

48. Hermansson, "'Ett så starkt ljus' av Lyra Ekström Lindbäck".

49. Ibid.

50. Rabe, "Kärleken i hjärnan". 
förhåller sig till och vittnar om ordens, språkets och tolkningarnas konkreta verkan i världen.

Ekström Lindbäck må vara upptagen av abstraktioner, men på ett sätt som oavlåtligt griper in i den sinnliga förnimmelsen av tillvaron. När Sara funderar på hur illa hennes erfarenheter platsar i verkligheten tänker hon på dem som sår och på sin kropp som översållad av dessa erfarenheters "bulligt vita ärr" ${ }^{51}$. När hon står på farstubron till sin mammas hus prasslar trädgårdens blad som "berättelser som bläddras undan, narrativ jag inte klarade av att vara kvar i" ${ }^{52}$ Sara är en av dem som "gång på gång stångar pannorna blodiga mot förbuden för vad som kan uppfattas som verkligt" ${ }^{53}$ Hennes oförmåga att leva enligt manus förpassar henne till ett bortom i förhållande till verkligheten. Som berättelse om den exkluderande effekten av normerande kulturella narrativ är Ekström Lindbäcks roman alltså inte någon abstrakt tankelek instängd i språket, utan en blodig historia. Manusen för acceptabla liv, de sanktionerade narrativen, skär in i huden. De bildar en fålla att banka sönder huvudet mot, och stakar, likt den kropp C är fången i, gränser kring begärsskildringen:

Hur huden drack av varje beröring, öppnade sig för upplevelsen utan att jag kunde sätta något emot, så har det aldrig varit förut. Osäkerheten om hur mycket jag fick röra hen tillbaka. Upphetsningen som fanns i hens händer mot min kropp, men inte i reaktionen på mina fumliga fingrar. ${ }^{54}$

I Saras minne av en natt med C är det bara en kropp som både förmår begära och bli begärd. $\mathrm{C}$ är stum under hennes fingrar. Kroppen hen inte upplever som sin är oförmögen att känna upphetsning. I skildringen av $\mathrm{C}$ framträder den koppling Braidotti tecknar mellan begär och ontologi som en negation. ${ }^{55}$ En kropp som inte kan låta sig begäras är en kropp som inte kan vara, och vice versa. Den avsaknad av sexuell drivkraft som recensenterna påtalar i boken framstår i min

\footnotetext{
5I. Ekström Lindbäck, Ett så starkt ljus, s. 7I.

52. Ibid.

53. Ibid., s. 46.

54. Ibid., s. I30-I3I.

55. Jfr Braidotti, Metamorphoses, s. 22.
} 
läsning som en kraftfull markering av sambanden mellan det formulerbara å ena sidan och det levbara och begärbara å andra sidan. C:s upplevelse av mötet förblir ett mysterium för Sara och följdriktigt oskriven i boken. Som en pendang till C:s avsaknad av upplevande kropp tecknar Ekström Lindbäck en outsäglighet, och därmed också en öppning för ett annat narrativ. När Sara funderar på att börja skriva är det följaktligen "om allt det som inte kan bli en berättelse" ${ }^{56}$ Hon vill formulera en i den av normen dikterade verkligheten omöjlig ordkropp där både hon och C kan rymmas, en berättelse som kräver att "villkoren för hur man är en begriplig person ska skrivas om". ${ }^{77}$ Uppbrottet ur de berättningsbara, begripliga och därmed verkliga manus vi är satta att följa utgör själva förutsättningen för den bok hon skriver inuti romanen.

Likt Ett så starkt ljus utspelar sig Taivassalos In transit i hög grad vid sidan om den giltiga, sanktionerade berättelsen om verkligheten. Galadriels förhållande med den gifta småbarnspappan George Gordon Junior existerar "[i]nte i den officiella versionen", utan i "en parallellvärld, en parentes" där det"finns en annan historia". ${ }^{58}$ Andra historier är vad Sems och Veras liv format sig kring. Bakom deras stillsamma åldrande i varsitt hus i hembyn ligger förbjudna kärlekar, parenteser av liv de har varit tvungna att försaka för den officiella versionens skull. I Galadriels fall begränsar sig inte avstegen från en sanktionerad livshistoria till en förbjuden kärleksrelation. Hennes kontinuerliga utlevelse av wanderlusten ter sig som en utdragen utbrytning ur den konvention som dikterar verkligheten.

"Kommer man ens fram någonstans?", undrar Anna-Lina Brunell i sin recension av romanen och sätter fingret på något centralt i dess variant av wanderlust. ${ }^{59}$ Bortsett från de arktiska fantasierna är det inte något specifikt mål som för Galadriel ut i världen. Det är tillfälligheter som gör att hon hamnar där hon hamnar och lusten som driver henne vidare. Räckvidden i Galadriels förflyttningar är imponerande. Ändå ter de sig statiska, som upprepade uppbrott mer än riktade rörelser. Detta drag framträder än tydligare i resedagbokens

56. Ekström Lindbäck, Ett så starkt ljus, s. I7o.

57. Ibid., s. I59.

58. Taivassalo, In transit, s. 369-370.

59. Anna-Lina Brunell, "Wanderlust, lust, konsumism", Hufvudstadsbladet 6/9 2016. 
skissering av transitplatser. Anonyma, likriktade och lösgjorda från de familjära sammanhangens bojor frigör transitplatserna jaget från ursprungets förpliktande förankring och förvandlar det till en närmast identitetslös" passage" som är"behagligt avlägsen, fristående, lösgjord, avskild från mig själv" ${ }^{60}$ Förflyttningen frammanar ett tillstånd av drivande bortom ursprung och mål, och det leder också bortom ett livsmanus dikterat av reproduktionen.

Den som är mest fjättrad av detta livsmanus är Sem. Frånsett sejouren i Stockholm lever han inställd på familj och fortplantning. Han återvänder till byn och ombesörjer såväl gårdens som släktens fortbestånd. Förväntningarnas internaliserade grepp om honom framgår av hans fördömande inställning till svägerskan Veras val att lämna byn och leva sitt liv utan hänsyn till vare sig ursprung eller reproduktion, att vägra de uppoffringar ett konventionellt livsmanus förutsätter. ${ }^{61}$ Vägrar dessa gör framför allt Galadriel. Det närmaste reproduktionen hon kommer är ett missfall som blöder ut på asfalten bland kulisserna i en Hollywoodproduktion. Hennes liv snarare fortgår än avancerar. Hon uppnår visserligen saker, men hon gör det om och om igen. Hon avverkar både arbetsplatser och kontinenter. Hon tar sig inte bara till en drömmarnas stad, utan till hela tre sådana. Till skillnad från Sem och Vera nöjer hon sig inte med hemkomsten som slutpunkt utan drar vidare igen. Samma repetitivitet präglar hennes sexuella utlevelse. Gång på gång väcks och växer hennes begär. Gång på gång blir hon uppfylld av George Gordon Junior i snudd på tvångsmässigt upprepade möten: "det finns ingen möjlighet att inte röra sig mot varandra, det går inte att hålla sig från att sugas in i den här rörelsen, det är o und vik ligt”. ${ }^{62}$

Galadriels konstanta genomresa innebär en provokation, inte bara i förhållande till ett målinriktat, reproduktivt liv, utan också mot den lineära progression från en början till ett slut som vi vanligen förväntar oss av en berättelse. När Galadriel introduceras är hon utmattad i Bombay, på tröskeln till beslutet att återvända hem. Där finner vi henne igen några hundra sidor senare. Men cirkeln tecknas bara för

6o. Taivassalo, In transit, s. Ioo.

6I. Ibid., s. 35 .

62. Ibid., s. 372 . 
att rivas upp. Vi färdas in i och ut ur berättelsen om hemkomsten, genom multipla uppbrott och uppfyllelser som genererar ett tillstånd snarare än ett förlopp. Förflyttningens konstans och uppfyllelsernas repetitiva överföd utmanar, likt tveksamheten i Ett så starkt ljus, ursprungets och målets överordning och entydighet. Galadriels livslinje bryter varken mot heteronormativiteten eller cisnormativiteten, men den är likafullt skev i förhållande till förhärskande sociokulturella och narrativa förväntningar på framåtskridande.

\section{RELATION TILL LITTERATUREN OCH BERÄTTELSEN SOM RELATION}

Romanernas trots mot manus, mot normativa mönster för såväl liv som narrativ, innebär inte något entydigt avståndstagande från allt vad berättelser heter. Tvärtom rör det sig i såväl In transit som i Ett så starkt ljus om en utforskning av möjligheterna och bärkraften i berättelsen som form och berättandet som strategi. Meretoja betonar det ömsesidigt dialogiska i relationen mellan kulturella narrativ och individuella uttolkningar av dessa. Som subjekt konstitueras vi i relation till normerande narrativa nätverk, men dessa nätverk existerar endast genom sina uttolkare, genom individuella subjekt. Här öppnar sig en möjlighet till omtolkning, en möjlighet där litteraturen kan ha en avgörande funktion både som material och metod. ${ }^{63} \mathrm{I}$ det följande diskuterar jag hur romanernas normkritik och alternativa poetik skrivs fram i produktiv relation till olika litterära narrativ och banar väg för hanteringen av berättelsen som en etisk relation.

Galadriels dröm om uppbrott och äventyr löper i Fridtjof Nansens spår. Det är mot hans reseberättelser hennes tonårsdrömmar tar form och när hon förverkligar drömmen om polen är det med hans arktiska upptäcktsresande som uttalad fond. ${ }^{64}$ Nansens resande utgör också en återkommande intertext i den resedagbok som romanens berättarjag för och reseskildringen som genre genomsyrar hela romanbygget. Således skriver romanen in sig i en utpräglat manlig tradition. Färden ut i världen för att erövra och upptäcka, geografiskt och erotiskt, är

63. Meretoja, The Ethics of Storytelling, s. 74, 77.

64. Taivassalo, In transit, s. 89, 463. 
- som Brunell påpekar $\mathrm{i}$ sin recension - en sliten intrig $\mathrm{i}$ vilken en ung man i regel spelar huvudrollen. ${ }^{65}$ När färden företas av en ung kvinna tycks intrigen dock ha potential att bli mer upprörande än upprepande. Att Galadriels erotiska erövringar är lika girigt många som hennes geografiska landvinningar har inte passerat obemärkt. In transit har lyfts fram både som ett välkommet exempel på litteratur som bejakar kvinnors kåthet ${ }^{66}$ och avfärdats som kiosklitteratur ${ }^{67}$ av samma orsak. Leken med konventionen kan avläsas i reaktionen.

Taivassalo låter inte läsaren glömma att In transit är ett stycke litteratur med hemvist i litterära traditioner. Både Galadriels namn och namnet på hennes mesta älskare George Gordon Junior klingar litterärt. Kärleksförmågorna hos Taivassalos George Gordon är av en kaliber som anstår en ättling till romantikens mästare George Gordon Byron, och Galadriels ovilja att låta livets realiteter sätta gränser för hennes blivande förlänar henne ett bortomverkligt, fantastiskt skimmer. Det utpräglat litterära draget i romanen signalerar en hemvist i litteraturen framom verkligheten.

”Jag är inte mitt geografiska ursprung", utropar Galadriel. ${ }^{68}$ Konstaterandet sätter inte bara ord på hela romanens grundpremiss: beredskapen att löpa, inte i jakt på ursprung, utan mot nya horisonter. Det framstår också som en anspelning på Monika Fagerholms moderna klassiker Diva (I998) där bojor knutna till sexualiteten avfärdas med en snarlik förkunnelse: "jag är inte per definition min sexualitet, som är per definition vild och obegränsad." ${ }^{69}$ Smeknamnet på Galadriels bror"Gullebjörnen" tecknar även det släktskap med Diva vars hjältinna också har björnbrorsor. Taivassalos författarskap är ett av de många kvinnliga författarskap som dykt upp i Fagerholms kölvatten. ${ }^{70}$ Med

65. Brunell, "Wanderlust, lust, konsumism".

66. Vilhelmina Öhman, "Dags att sluta gömma undan kvinnors kåthet”, Yle Kultur \& nöje I2/2 20I7, https://svenska.yle.fi/artikel/20I7/o2/r2/dags-att-sluta-gommaundan-kvinnors-kathet (hämtad I/3 20I7).

67. Robin Valtiala, "Roman som ett lapptäcke", Lysmasken, I7/3 20I7, http://www. kiiltomato.net/hannele-mikaela-taivassalo-in-transit/ (hämtad 20/3 2017).

68. Taivassalo, In transit, s. 380 .

69. Monika Fagerholm, Diva: en uppräxts egna alfabet med docklaboratorium (en bonusberättelse ur framtiden), Helsingfors: Söderströms I998, s. 84-85. Fetstil i original.

70. Jfr Tuva Korsström, Från Lexå till Glitterscenen. Finlandssvenska tidsbilder, läsningar, författarporträtt 1960-20I3, Helsingfors: Schildts \& Söderströms 20I3, s. 50I; Kristina Malmio \& Mia Österlund, "Introduction”, Kristina Malmio \& Mia Österlund 
blinkningarna till Diva framhäver Taivassalo romanens delaktighet i den stilistiska och tematiska omorientering som präglat de senaste decenniernas finlandssvenska litteratur och för vilken just Diva har lyfts fram som en nod. ${ }^{71}$ Genom att avfärda det geografiska ursprunget i stället för sexualiteten skriver hon uttryckligen in sig i den tendens att utvidga det geografiska rummet som präglat den finlandssvenska 2000-talslitteraturen. ${ }^{72}$ Taivassalos roman rör sig följaktligen inte bara ut ur vedertagna och normerande manus och intriger, utan också in i större tendenser och traditioner.

Galadriels resande vittnar inte endast om wanderlust, utan också om en oförmåga att stanna. Idéhistorikern Karin Johannisson beskriver den planlösa flykten som en särskild depressionsavvärjande strategi. Sjukdomstillståndet, kallat "fuga", spred sig som en epidemi i Europa kring sekelskiftet I900. Då var "fugueuren" alltid en man och flykten kopplad till identitets- och minnesförlust. För kvinnorna var de geografiska flyktmöjligheterna ännu begränsade. Deras resor företogs i stället inuti den egna personen och tog sig uttryck i personlighetsklyvning och hysteri. Fugan genljöd också i skönlitteraturen där såväl hungern efter frihet som uppbrottet från förkvävande sammanhang var populära motiv. I litteraturen kunde också kvinnor ta till flykten, som exempelvis Henrik Ibsens Nora. ${ }^{73}$ Galadriels resande ter sig ofta planlöst. Det är kopplat till en lust att frigöra sig från sig själv framom ett tvång att finna sig, drivet av flykten snarare än av målet. Därmed framstår Galadriel som något av en fugueur, som en 2000-talsvariant av åkomman möjliggjord av ett sekel av kvinnofri-

(eds.), Novel Districts. Critical Readings of Monika Fagerholm, Studia Fennica Litteraria 9, Helsingfors: Finnish Literature Society 20I6, s. II, https://doi.org/Io.2I435/ sflit.9.

71. Kristina Malmio, "Phoenix-Marvel Girl in the Age of Fin de siècle - Popular Culture as a Vehicle to Postmodernism in Finland-Swedish Author Monika Fagerholm's Novel Diva (1998)", Leena Kirstinä (ed.), Nodes of Contemporary Finnish Literature, Studia Fennica Litteraria 6, Helsingfors: Finnish Literature Society 2012, s. 72-95, https://doi.org/Io.21435/sflit.6.

72. Tendensen har kartlagts inom forskningsprojektet Senmodern spatialitet i finlandssvensk prosa I990-20ro. Se t.ex. Kristina Malmio,"Post scriptum: Senmodern spatialitet i finlandssvensk prosa", Avain. Kirjallisuudentutkimuksen aikakausilehti 2018:3, s. I62-I7I.

73. Karin Johannisson, Melankoliska rum. Om ångest, leda och sårbarhet i förfluten tid och nutid, Stockholm: Bonnier pocket 20Io [2009], s. I77-I87. 
görelse i kombination med billiga flygbiljetter. Hon är en ättling till Nora som knappt hinner flytta in i dockhemmet innan hon lämnar det. Även om wanderlustens melankoliska skuggsida skymtar fram i romanen är In transit varken en svartmålning eller en patologisering av rörligheten. Den är, vilket jag snart ska återkomma till, framför allt en utforskning av rörlighetens relationsskapande möjligheter.

Trots den utpräglade skepsisen mot normativa narrativ väjer inte heller Ett så starkt ljus för väl upptrampade berättelsestråk. Som generationsroman aktualiserar den en beprövad konvention. Som påpekats i receptionen är det inte första gången medelklassens medelålders medelsvenssöner blir föremål för kritik i denna genre. Idén om författarblivande genom kärlek, genom att avverka muser, är heller inte ny. Däremot är det i båda fallen frågan om grabbiga konventioner. Recensenterna gör kopplingar till Ulf Lundell och Klas Östergren. ${ }^{74}$ Det är med mönster för manlig frigörelse och tillblivelse i botten som Ekström Lindbäck stakar ut sin hjältinnas väg. Och den vägen leder uttryckligen in i en berättelse, som i detta fall är en berättelse om tillkomsten av en roman och därmed en tematisering av det specifika blivande som är författarens.

Att mönstret i detta fall skildras med queera förtecken bidrar till att förankra romanen i nuet, i det decennium som sett pronomenet "hen" befästas och cis-normen krackelera. På de få år som gått sedan Ekström Lindbäcks roman utkom har transfrågor slagit igenom på bred front exempelvis genom populärkulturella storsatsningar som filmen The Danish Girl (2015), internationella bästsäljare som Maggie Nelsons The Argonauts ${ }^{75}$ och högljudda debatter som den transdebatt som rasade i Sverige vårvintern $20188^{76}$ Romanens ämne ligger i tiden, men $\mathrm{i}$ hanteringen av det ekar konventioner som beprövats långt tidi-

74. Jfr Bergström,"Lesbisk jakt efter identitet och flickor"; Hermansson,"'Ett så starkt ljus' av Lyra Ekström Lindbäck".

75. Maggie Nelson, The Argonauts, Minneapolis: Graywolf Press 2015.

76. Startskottet var en opinionsartikel av Kajsa Ekis Ekman där hon reflekterade över vad som händer när vi inte längre kan tala om biologiskt kön. Se Kajsa Ekis Ekman, "Könet i knoppen", Aftonbladet I7/1 2018. Den tolkades som ett ifrågasättande av transpersoners existens och gav upphov till en animerad diskussion, se t.ex."Så har turerna gått kring Kajsa Ekis Ekman och transfeminismbråket", SVT Opinion 7/3 2018, https://www.svt.se/opinion/kajsa-ekis-ekman-och-transfeminismbraketdetta-har-hant (hämtad 26/ı 2018). 
gare i litteraturhistorien. Föreställningen om "alla vanliga människor", vars vanliga liv Ekström Lindbäck låter sitt persongalleri bryta mot, är en idé som det litterära avantgardet strävat efter att befästa, inte bara på 1960- och 1970-talet utan redan under modernismen och romantiken. Romantiska föreställningar om konstnären går igen i Ett så starkt ljus och det är från romantiken dess viktigaste intertext härrör. Av vännen Emil förses Sara med smeknamnet Tintomara. Därmed tecknas en koppling till C.J.L. Almqvists Drottningens Juvelsmycke som redan I834 ställde läsaren inför androgynen och frågan huruvida androgynen bör förstås som en varelse "som är ingendera könet, eller beggedera" ${ }^{77}$ Ett så starkt ljus är en litterärt bevandrad roman, och litteraturen bär på en överlevnadsstrategi för dess huvudperson."Fiktionen är ju till för sådana som jag", konstaterar Sara när hon dryftar verklighetens smärtsamma begränsningar och nödvändigheten av att hålla ett "pyrande 'något' vid liv inom oss". ${ }^{78}$

Fiktionen, berättelsen som vidgning av det möjliga, blir Saras väg genom en av förringande narrativ dikterad verklighet, och denna väg leder in i metafiktionen. Även här skriver Ekström Lindbäck in sig i en både beprövad och aktuell tradition. Bo G Jansson hävdar i sin karaktäristik av den svenska prosaberättelsen från millennieskiftet till nuet $^{79}$ att dess rörelse mot självbespegling och metafiktivitet är mer påtaglig än någonsin. Han lyfter också fram en stark jagcentrering som typisk för den svenska nutidsprosan och pekar därmed på ett annat drag som återfinns i Ett så starkt ljus. Men när Jansson hävdar att

77. Carl Jonas Love Almqvist, Red. Lars Burman, Samlade verk 6, Törnrosens Bok. Duodesupplagan. Band IV, Drottningens Juvelsmycke, Stockholm: Svenska vitterhetssamfundet 2002 [1834], Litteraturbanken, https://litteraturbanken.se/ forfattare/AlmqvistCJL/titlar/SamladeVerk6/sida/III/etext (hämtad I9/6 20I9), s. 53, kursiv i originalet. Inom ramen för denna artikel har jag inte möjlighet att spinna vidare på de spår som kopplingen till Almqvist tecknar. Ett så starkt ljus inbjuder till vidare transteoretisk och translitteraturhistorisk läsning. För en sådan utgör Tintomara-gestalten en given ingång. Sam Holmqvist nämner också kortfattat Ekström Lindbäcks roman som en samtida variation på Tintomara-traditionen i sin translitteraturhistoriska avhandling om bland annat Almqvist. Se Sam Holmqvist, Transformationer: I8oo-talets svenska translitteratur genom Lasse-Maja, C.J.L. Almqvist och Aurora Ljungstedt, Göteborg \& Stockholm: Makadam 20I7, s. I5I-I53.

78. Ekström Lindbäck, Ett så starkt ljus, s. 46.

79. Bo G Jansson, Ljuga vitt och brett utan att ljuga. Den svenska prosaberättelsen i den postmoderna skärmkulturens tidevarv: fllosofisk grund, innehåll och form, Rapport I/20I3, Kultur och vetande, Falun: Högskolan i Dalarna 2013, s. 9-ıo. 
nutidsprosan präglas av bristande framtidstro och att dess grundton är dystopisk blir karaktäristiken för trång för Ekström Lindbäcks roman. Ett så starkt ljus bär, precis som In transit, på ett värn mot svartsyn. Det värnet ligger i relationen, i utforskningen av berättandets förmåga att omfatta och uttrycka ett relationellt blivande.

Braidotti beskriver blivande som ett tillstånd av sammankoppling, som kommunikation och ömsesidig kontamination mellan erfarenheter. Hon poängterar att det inte handlar om platt imitation eller upprepning, utan om ett slags intensiv empatisk närhet. ${ }^{80}$ Galadriels rörliga leverne tar henne ut i världen, men samtidigt också i riktning mot andra livslinjer i romanen. Det sätter henne i relation till de andra karaktärernas levda erfarenheter och avklippta drömmar. Berättelsen om det oundvikliga i Galadriels relation till George Gordon Junior blir bokstavligen en berättelse om Veras upplevelse av att vara den andra kvinnan."Det var någonting med våra kroppar som bara hände”, berättar Galadriel om sin upplevelse i ett samtal med Vera, och sätter därmed ord också på Veras erfarenhet. Galadriel återger sin historia, men beskrivningen blir bådas, "som om det inte var säkert vem av dem som sade detta, vem av dem de talade om" ${ }^{81}$ På handlingsplanet framträder en metanarrativ tematisering av berättelsen som den ömsesidiga, empatiska närhetens förutsättning. När erfarenheten av att vara den andra kvinnan berättas löper Veras och Galadriels enskilda och ensliga, förtigna parenteser in i varandra. Med Meretoja kan man säga att berättelsen därmed framträder i egenskap av ett narrativt mellanrum, som en förenande kraft över tids- och generationsgränser. ${ }^{82}$

I relation till Sems och Veras liv tecknar Galadriels livslinje mer än en upprepning. Hon håller de alternativa livslinjerna levande genom att dra dem ännu längre. När hon i slutet av romanen ringer Vera ur "en av många" framtider, är det från den stad där Vera en gång "arbetat och dansat". Att Galadriel också hör av sig till George Gordon Junior är en signal om att hon inte har tänkt göra som Vera och Sem och frånsäga sig begäret. ${ }^{83}$ Den erotiska uppfyllelsens laddning där

8o. Braidotti, Metamorphoses, s. 8.

8I. Taivassalo, In transit, s. 318, jfr s. 3I4.

82. Meretoja, The Ethics of Storytelling, s. II7.

83. Taivassalo, In transit, s. 465-467. 
"alla molekyler ändrade förening, blev någonting annat, reagerade", är som en köttslig variant av romanens formmässiga korsklippning och sammanskrivning av liv, tider och platser. ${ }^{84} \mathrm{Ur}$ begäret föds ett blivande som inte väjer för gränser och ett berättande som bejakar öppenheten mot annat och andra.

Uppfyllelsen av Galadriels dröm om Arktis som avrundar romanen framstår som ett destillat av detta blivande. Själva resmålet, ett förkroppsligande av förgänglighet i klimathotets tidevarv, understryker uppfyllelsens tillfällighet. Resan tar Galadriel bortom civilisationen och bortom henne själv. "Kanske är det helt enkelt inte så viktigt med människan här", tänker hon och identifierar sig med en isbjörn, ett solitärt djur. ${ }^{85}$ Men genom hennes färd ut ur gemenskapen löper en rörelse i motsatt riktning. Galadriel färdas i Nansens spår och hennes upplevelse av polen färgas av hans blick. Begäret efter att uppgå i Arktis är något som romanen igenom förenar Galadriel med resedagbokens jag. "Jag är orädd, orörd, förseglade glaciärer", ljuder fantasin om polen i ett avsnitt som varken tillskrivs Galadriel eller dagboksjaget och som därmed rymmer dem båda. ${ }^{86}$ På slutet bordar de vad som förefaller vara samma båt som tar dem ut mot isvidderna. Ur den arktiska tomhetens oskrivna vithet stiger en narrativ knutpunkt och ett drömmarnas nav. Berättelsen och begäret löper samman i ett ingenmansland som förenar. I Galadriels resa till ensamheten framträder en vitt famnande delaktighet, en relation.

Blivandet i Ett så starkt ljus är både mera riktat och mera kringskuret. När Sara väljer att börja skriva sitt liv fjärmar hon sig också från det. Hon ger upp hoppet om en relation med $\mathrm{C}$ och låter sig dras in i ett förhållande hon är uppenbart ointresserad av. Det hon intresserar sig för är berättelsen hon skriver. Den blir hennes främsta relation, rentav en sängkamrat. I den ödsliga lägenheten där hon ligger och funderar på det rättmätiga i att fläka ut "avigsidorna" i sitt och andras liv prasslar pappren under henne, rispar hennes nakna hud och påminner henne om den kropp som är hennes utgångpunkt, egen och "[b]ebodd av alla som har umgåtts med den, om så bara genom

84. Ibid., s. 4II.

85. Ibid., s. 470-47I.

86. Ibid., s. 95 . 
en blick" ${ }^{87}$ Den frånvända, skrivande tillvaron bär, likt den ensamma kroppen, på en kollektiv erfarenhet, en delaktighet.

Skrivandet är sprunget ur en upplevelse av delaktighet och är också i sig en form av delaktighet: "Du skriver för oss, eller hur?' [...] 'Men du skriver också för dem', sammanfattar Emil Saras projekt och sätter samtidigt ord både på dess särskiljande av den egna queera kretsen från en förhärskande normalitet och på berättelsens potential som intersubjektiv konfrontation mellan dessa sfärer. ${ }^{88} \mathrm{I}$ sitt försök att formulera ett alternativt utrymme för de queera erfarenheter som är hennes, C:s och Emils vänder hon ryggen åt"den vanliga människan”, åt konventionella mönster för liv. Därmed upprättar hon en skiljelinje mellan "oss" och "dem". De narrativa mellanrummens förmåga att förena bär, som Meretoja påpekar, också på sin motsats. Narrativa mellanrum upprättar ett innanför och därmed även ett utanför. De separerar, skiljer ut och bort. ${ }^{89} \mathrm{I}$ Ett så starkt ljus framstår detta utestängande som en förutsättning för att berättelsen alls ska vara möjlig. Och i denna förutsättning skymtar paradoxalt nog också en relation. Genom att skriva in normen, om så bara för att vända den ryggen, visar Ekström Lindbäck på ett ömsesidigt beroende mellan den queera kretsen och den omvärld som kringgärdar den. Berättelsen skiljer dem åt och slår därmed en bro dem emellan. Berättelsen framträder som en relation med kraft att skapa en relation.

Saras hållning till berättelsen uppvisar en konstant vacklan mellan underminering och tilltro. Här är C korrektivet som uppenbarar berättelsens etiska nödvändighet och begränsningarna i dess räckvidd. Hen är "som en ström av tillstånd [...] ett ogenomträngligt pågående" ${ }^{90}$ och dessutom "ointresserad av att språkliggöra känslor" ${ }^{91}$ I C framträder någon som varken ord eller narrativ kan omfatta, men därmed också någon som berättelsen måste försöka nå. Vissheten om att det berättningsbara sätter gränserna för det levbara är vad Saras bok blöder ur och ärrar sig kring. Det är mot bakgrund av denna visshet Sara hävdar både sin berättelse och dess felbarhet: "Det går

87. Ekström Lindbäck, Ett så starkt ljus, s. 251.

88. Ibid., s. 259-26o. Jfr Newton, Narrative Ethics, s. 3-8.

89. Meretoja, The Ethics of Storytelling, s. I20.

90. Ekström Lindbäck, Ett så starkt ljus, s. I34.

9I. Ibid., s. I42. 
att skildra. Det kanske blir en klumpig berättelse som ingen vill läsa, men det finns ett språk." 92 Saras berättelse vittnar om en insikt å ena sidan i berättelsens bristfällighet och å andra sidan i dess begränsande allmakt. Att berätta den är ett försök att vidga verkligheten till att omfatta dem för vilka det varken finns språk eller kropp. Att framhålla berättelsens otillräcklighet är att värna dess öppenhet och besvärja dess begränsande makt. Relationen till det som befinner sig bortom berättelsens räckvidd utgör den begärsfyllda drivkraft som avkräver berättelsen ett fortsatt blivande.

\section{ÖVERFLÖDETS OCH TILLKORTAKOMMANDETS POETIK}

Såväl Taivassalo som Ekström Lindbäck skriver samman berättelsen och blivandet. Begäret som driver både Taivassalos överflödande rörlighet och Ekström Lindbäcks produktiva tillkortakommanden röjer kopplingen mellan poetik och etik. Båda erbjuder distans till och kritiska perspektiv på normaliserade och normerande narrativa identiteter. Ekström Lindbäcks jakt på ord för livslinjer bortom de sanktionerade och formulerbara blottar berättelsens begränsningar - dess oförmåga att ge rum för avvikande erfarenheter och identiteter - men också dess kraft att trotsa dessa begränsningar. Taivassalos oupphörliga passage mellan stilar, tider, identiteter och platser värnar om mellanrummen, kopplingarna och övergångarna mot det som ännu inte är.

På sinsemellan olika sätt demonstrerar Ett så starkt ljus och In transit berättelsens kapacitet att röra sig från det givna mot en vidgning av det möjliga, att överskrida gränserna för det som kan berättas och därmed också levas. I deras respektive förverkligande av berättelsens relationella öppenhet avtecknar sig berättandet som en ständigt fortgående etisk reflektion. I Ekström Lindbäcks och Taivassalos tappning framstår berättelsen därmed som en relevant form för att uttrycka och utforska den konstanta föränderlighetens komplexitet.

92. Ibid., s. 242, kursiv i originalet. 